\title{
The Application of Solutions Journalism: Strategic Communications and Public Affairs Group in Somalia
}

\author{
Dilan Ciftci \\ Assist. Prof. Dr., Department of Journalism, Near East University, Near East Boulevard, Nicosia, \\ CYPRUS \\ (1D) 0000-0003-3806-3915 SC 57196473364 D-2953-2013 \\ dilan.ciftci@neu.edu.tr
}

ARTICLE INFO

Received: 28 March 2019

Accepted: 6 May 2019

Published: 14 May 2019

DOI: https://doi.org/10.29333/ojemt/5782

ABSTRACT

The aim of the current study is to explore the strategic transition from traditional peacekeeping operations to current peacekeeping operations and the conceptual development of solutions journalism with an emphasis on the United Nations Assistance Mission in Somalia (UNSOM) in general and special focus on the Strategic Communications and Public Affairs Group (SCPAG) activities during the Somalia's 2016 electoral process. In total, 72 videos from Vimeo UNSOM SCPAG channel were coded with regards to conflict frames and solutions journalism during the Somalia's 2016 Electoral Process. This study provides an overview for the transition from traditional peacekeeping to current peacekeeping operation in order to map the differences in application of UN peacekeeping operations by using already existed studies on the historical background of peacekeeping operations were reviewed. The present data suggests that UN peacekeeping operations in general, and more precisely UNSOM SCPAG have an impact on the strategic communications during the Somalia's 2016 electoral process, which might be explained as an example of successful solutions journalism. In findings indicate that Somalia's 2016 electoral process with the help of the UNSOM SCPAG demonstrated not only higher interest on the electoral process, but also higher number of women seats in the parliament as well that it can be said that UNSOM SCPAG activities adopting an active solutions journalism role.

Keywords: current peacekeeping operations, solutions journalism, strategic communications, UNSOM SCPAG, Somalia's 2016 Election

\section{INTRODUCTION}

Somalia presents an exclusive opportunity for the investigation for not only comprehensive understanding of the solutions journalism with special reference to strategic communications and public affairs activities due to its alive and successful postconflict peacebuilding facilitates. Currently, there is no comprehensive study that incorporates the conceptual development of solutions journalism for the Somalia's 2016 Electoral process and critical communicative achievements. In this study, in order to put the significant differences in the current peacekeeping operations, the historical background of peacekeeping and traditional peacekeeping operations will be analyzed in the wide spectrum with special references to different peacekeeping operations all around the world. Then, this study will evaluate United Nations Assistance Mission in Somalia 
(UNSOM) Strategic Communications and Public Affairs Group (SCPAG) videos in order to check the application of the solutions journalism. For this purpose, this study will continue with a discussion on the conceptualization of solutions journalism and its potential role in the emergence of peaceful future. While this conceptual discussions are going on the table, there is a need for a special reference to UNSOM SCPAG activities. Therefore, in this study before the evaluation of the videos, the UNSOM SCPAG and its produced materials will be introduced to draw an attention to how an international organization by itself played an enormous role for providing the basis for emergence of solutions journalism in conflict areas.

This study enables the discussion of strategic communication in a different way of thinking by providing the political view in it. Generally speaking strategic communication has conceptual umbrella that enables communications amongst stakeholders by disparate messaging efforts. Moreover, the consistency reinforces the organization message across all media platforms. The application of strategic communications mainly occurs with strategic planning, stakeholders talk, developing actionable objectives, develop and priorities potential strategies and tactics and metrics of responsibilities. By examining UNSOM SCPAG in many different ways not only opens a new path to look current peacekeeping operations but also delivers new conceptual discussion combination with the peacekeeping studies and communication studies. This special case of UNSOM SCPAG is truly fits to look deeply the application of the strategic communication in peacekeeping operations and shows the potential positive effects of it.

\section{Historical Background of Peacekeeping}

League of Nations (LON) was created as a result of Treaty of Versailles, which will be later as precursor to the establishment of United Nations. The reason that leads to failure for LON was the idea of isolationism by US. However both organizations were established by initial aim, which includes the motto of 'peace and security'. The main difference between LON and UN is that contrary to LON, UN forced, and will be continuing to force for peace. By UN responses to Suez Crisis of 1956, first peacekeeping operation took place, which was not only established the nature, but also the character of most UN peacekeeping operations until the mid-1990s (Ramsbotham et al., 2005; Laqua, 2015; Pedersen, 2015). Especially the crucial reasons of establishing peacekeeping, "The catastrophic loss of life and physical devastation caused by the war, coupled with the invention of the atomic bomb, convinced international leaders that international organization was more necessary than ever." (Bellamy et al., 2004).

Moreover, Ryan (2000) argued that UN peacekeeping operations started as unplanned responses at a particular time in order to prevent total wars. In addition, he emphasized that during the Cold War period UN peacekeeping operations had to play the role in precluding that local conflicts did not escalate to larger regional neighbors, or two superpowers. Effectively, Ryan (2000) propounded that the most effective events in constructing UN peacekeeping nature were the chances of Greek-Turkish war in Cyprus and Israeli-Syrian war in Lebanon. In the light of this information, one can argue that no one really thought it would get involved in military operations when it was first settled up. Yet, the ambiguity of status and the changeable nature in the UN peacekeeping operations were come from the beginning.

\section{Peacekeeping Operations from Traditional to Current}

In the light of above information, this part of the study will respectively highlight the first and second generation peacekeeping operations. According to Ramsbotham et al. (2005), first generation peacekeeping operations mostly liked to act in inter-state conflicts 
such as; during the Cold War period Britain and Argentina or Iran-Iraq War. Similarly, in the post-Cold War period we were still witnessing the famous inter-state conflicts like between Iraq and USA. The main functions of first generation peacekeeping operations were monitoring border and generating buffer zones where need of natural body to observe the peace process (Ramsbotham et al., 2005). As it is clear in the definition, first generation peacekeeping instead of fighting against one group or another aimed to monitoring with small military troops, which were composing soldiers from members of UN, who has naturally small armed troop contingents.

Although peacekeeping has differed from time to time and region to region the most famous example of first generation peacekeeping operations is Cyprus, which had terrible events in 1974 during the notion of confrontation through détente in the world Cold War. Historically, Cyprus was a controversial area because of not only its geo-political importance for its neighbors, but also titled under the minority-majority problem. From past to present both communities (Turkish Cypriots and Greek Cypriots) tried to come together and negotiate for their joint interests, because of the rising nationalistic ideology during the Cold War and segregationist attitudes of both community leaders disrupted peace process. Yet, there were some deficiencies in first generation peacekeeping operations' agenda, which were uncertainty in many aspects such as; clear types of mandate or rules of military engagement.

On the other hand, obviously the way of practicing and engaging peace settlement had to be changed with regards to lessons learned from deployment when more complex conflict environment had emerged (Ramsbotham et al., 2005). The main characteristics of second generation peacekeeping operations would be listed as; 'multilateral, multidimensional, and multicultural' (Ramsbotham et al., 2005). Significantly, multilateralism implies different actors, which can conduct in involvement of several operations. Here, according to functionalists approach IOs or NGOs by creating networks between states and agencies can help eliminating war and promoting peace.

Moreover, the nature of multidimensionality separate components of the society which would incorporate with each other by functioning compatible. "Essentially, the military component's function was to serve in a supporting role: to guarantee and maintain a secure environment in which the civilian components could conduct their work." (Ramsbotham et al., 2005:136) To put more emphasis on division of components, it is crucial that while military components involves to cease belligerents and its events, civilian components' power work under the base of social process in peacekeeping that is diplomatic, economic, ideological, scientific and technical, humanitarian and legal (Ramsbotham et al., 2005: 137). At his point dealing the world humanitarian or human rights is not coincidence that we were later witnessing the huge human rights violations in many different areas in the world. Therefore, the indicator of general good governance has been noted. To illustrate this Ryan (2000) focused on the specific example of second generation peacekeeping operations.

Since the end of the Cold War we have witnessed 'second generation' peacekeeping in Namibia and Cambodia where the status quo ante has been rejected and where the aim is to construct a more peaceful and just society less prone to violence. Such attempts may not have been entirely successful, but they deserve recognition as a new type of mission (Ryan, 2000: 33).

To pick up all these information, the traditional peacekeeping operations acting impartially between the parties aim to use minimum extent of force. Yet, the main task 
of UN troops was the inter-positioning of warring parties that they were already permanent ceasefire. Necessarily, such operations were organized by three key principles of consent, impartiality, and minimum force. On the other hand, recent peacekeeping operations differ in some bases with regards to Cold War predecessors by environment, principle and practice. Particularly second generation peacekeeping operations rather than first generation peacekeeping operations have seen UN forces intervene in the middle of civil wars, which implies that they are still hot instead of frozen or remission. In other words, second generation peacekeeping operations had active role not only after any ceasefires, but also they had play dynamic role in the conflict time.

The decline in troop numbers, decline of peacekeeping missions and decline of budgetary resources brought about the shift the direction of UN attentions towards the threat of bad examples, Somalia, Rwanda, and Bosnia. The most obvious shortcoming of first and especially second generation peacekeeping operations could be observed in the transition between wars during the cold war and the nature of new wars. According to Ramsbotham et al. (2005), the new wars included warlordism, militias and black economies. Differently, while in the Cold War period enemy was apparent with distinct uniforms, but during the new wars period distinction between fighters and civilians almost impossible. Dramatically, as Ramsbotham et. al. (2005) quoted Duffield's ideas "civilian are seen as resource base to be either corralled, plundered or cleansed" (Ramsbotham et al., 2005: 139) Besides, the concern of women, children or elderly, which implies humanitarian base, were disappeared. Deliberately, the destruction of the daily life had placed whole populations in a position of dependence on the combatants. Moreover, the disarmament in the peace processes was also the controversial part of the peacekeeping operations that needs certain strategies on this subject. As Ramsbotham et al. (2005) quoted the Cooper (2001) interpretation on this issue, his suggestion on strategies mostly designed to apply the trade in conflicts goods, as in the case of Sierra Leone's conflict diamonds.

Gradually, the nature of new wars really came to a head with the ending of the Cold War and the humanitarian disasters in US force in Somalia, Rwanda and the NATO airstrikes in Former Yugoslavia. Particularly, the lessons that learned from Rwanda were vital for conducting the nature of third generation peacekeeping operations. First, after these humanitarian disasters it had been understood that UN should seriously take the early warning in order to prevent due to overload. Second, the UN peacekeeping operations should make major reforms with regards to humanitarian agencies. Third, the UN peacekeeping operations firmly manage to organize their arms flows in the conflict.

Clearly, the most significant problem that is supposed to overcome is objectivity of UN peacekeeping operations. Yet, as it is clear in Somalia or many other humanitarian bad examples the impartiality as it could applied in the Cyprus was not enough to stop undesired events. In such cases that were occurred after Cold War period had impact on the necessity of mentioning 'human security' suggests, impartiality is not workable where the notions of structural violence had placed. In the light of these explanations one could come one single conclusion that without the notion of consent, the idea of neutrality and the need of impartiality third generation peacekeeping operations most likely identify as peace enforcement rather than peace making.

Solutions Journalism

Solutions journalism is an approach where reports are not only focusing on the social issues but also the problems themselves as well. in other words, solutions journalism stories anchored in credible evidence for necessity of solutions by explaining how and why 
responses are working and not working. In this approach, the goal is to present more complete view of these issues in order to help citizens to drive more effective citizenship. According to Wenzel et al. (2016) argue that there is an accepted understanding of if it bleeds, it leads continues to resonate journalistic environment. In other words, Wenzel and et. al criticize that the professional bias of journalists are in favor of reporting on violence, crime, policy brutality, and other negative issues. Also, they argues that audiences are more interested in these negative stories.

Significantly, Aragones (1997) in study entitled by Negativity Effect and the Emergence of Ideologies talks about the relationship between the negative stories and audiences process negative information helps to contextualize negative journalism frames. Aragones (1997), emphasizes that citizens perceptions of candidates and voting behavior might possibly be affected by the negative stories. Meffert et al. (2006) explain the relationship between the negativity of political story and possibility of clicking the hyperlink. In other words, they argue that readers are more likely to click hyperlink with a negative issues than positive ones. With the developments and changes around the internet based applications, hyperlink and so on become a vital thing. In this sense, social media and its creativity opportunities are very crucial for providing the platform for enlarging the awareness amongst the followers (Ulas \& Vural, 2019: 2).

Moreover, Brader (2005) emphasize the important conclusion that negativity in news stories or negative framing in other words, might be risky for the realm of the political, humanitarian, and social change campaigns, which we might put UNSOM SCPAG under this category as well. According to Shah and et. al. (2007) although some scholars believe that negative framing catches the attentions, others found that negative news stories about social issues cause audiences to stop seeking information. Furthermore, Feinberg and Willer (2011) emphasize the boomerang effects by using the example of climate change communication in their work on Apocalypse Soon?: Dire Messages Reduce Belief in Global Warming by Contradicting Just-World Beliefs. Feinberg and Willer (2011) found that audiences with a boomerang effect became more skeptical about the climate change if they exposed to dire messages on global warming phenomenon. In addition to that, Cohen (2001) highlights that in the humanitarian campaigns when messages trigger a sense of hopelessness evoke audiences guilt. According to Wenzel et al. (2016) negative stories may be highly salient to audiences, which it is hard to explain the reason behind it.

Rosen (1999) argues that solutions journalism developed from the some concepts among peace and civic/ public journalism which became popular with the creation of the Solutions Journalism Network in 2013. Eventually, the Solutions Journalism Network became a leading player in solutions journalism when stories are responses to social problems. Moreover, Kurpius (2002) emphasizes that solutions journalism might not be understood as good stories or good news. Therefore, Kurpius defines solution journalism as a stories have newsworthiness and present solutions for the country's rather than problems by covering the range of local, national and international issues as an advocacy pieces.

To make clear discussion on solutions journalism and new media tools, it is true to say that they were go along with the one and another in Somalia case. Moreover, 'While the development of digital communication technology has introduced new functionality into our lives, such as multi-media, interactivity and connectivity, this advanced technology has also created new journalistic opportunities by developing new structures within the media industry' (Çatal, 2017: 7463). Thus, Solutions Journalism Network websites 
defines this practices as a kind of investigative reporting that is for to discover systematic underlying reasons for social problems. Therefore, according the Solutions Journalism Network, solutions journalists put efforts on the critical examination to address the social issues, which are not necessarily a problem has a quick ending. Furthermore, Galtung and Ruge (1965) support that there is an increasing number of media organizations which create a platform for solutions journalism by appreciating the problem solving efforts. As Solution Journalism Networks websites declares that solution journalism has potential for revenue generation by offering fresh eyes for positive innovation, where those stories compromise possible new models as well.

Along with the above explanations it is also crucial to mention the website role in the solutions journalism process. As peacekeeping operations were static and isolated before the media come before the scenario. 'Over time users and developers have figured out the unique strengths afforded by the web's capabilities, and as the literal form and content of the internet have developed, so too has the actual culture of the internet such that the internet can be considered a distinctive culture' (Sheldon \& Romanowski, 2018: 293). In addition to that, Ciftci (2014) in her study made the criticism on the UN peacekeeping operation in Cyprus by neglecting the media's ability to promote peace in conflict resolution and negotiation process especially in the Annan Plan Referendum (Ciftci, 2014: $57)$.

\section{UNSOM and Strategic Communications and Public Affairs}

UNSOM's strategic communications in support of Somalia's 2016 electoral process might be accepted as a successful examples of how solutions journalism practices work. UN Reports from UNSOM official websites defines SCPAG as a campaign for conducting the strong civic education, which provides several important education on credibility of the electoral process and capacity building workshops for Somalian journalists. Here, it is very vital milestones for Somalian journalism history, because Somalian journalists have started provide investigative reporting for better Somalia which is solely solutions journalism as well. At the same time, it is also unique for SCPAG that their activities reached youth and women, which designated to provide educated women candidates for Somalia 2016 election. Again, SCPAG here by itself provides a meaningful example of solutions journalism outside the local journalists. In other words, as it is discussed earlier in the transition from traditional to current peacekeeping operations, UNSOM with special reference to SCPAG is beyond the current peacekeeping operations with it numerous success in gender equality in politics, professionalization of media and youth awareness of future. According to UNSOM's official report UNSOM SCPAG campaign consisted of six major strands. These are:

- Communication support to the Federal Indirect Electoral Implementation Team (FIEIT)

- Promotion of the 30 per cent quota of parliamentary seats for women candidates

- Civic education activities to promote the credibility of the electoral process

- Capacity-building of Somali journalists for covering the electoral process

- International media outreach activities

- Ensuring that the international community spoke with one voice on issues related to the process

On the other hand, it is necessary to mention the material that were produced by the UNSOM SCPAG for Somalia's 2016 electoral process. These materials presents an accurate examples of how current peacekeeping operations might be better and 
unpredictably achieve stable success if they consider more on having place for the emergence of solutions journalism in their activities where conflicted societies pursue for peace. In the light of this information, the materials of UNSOM SCPAG could be listed as such:

- Hayaan radio talk show - Haboon radio drama series - Tubta Nabada magazine talk show
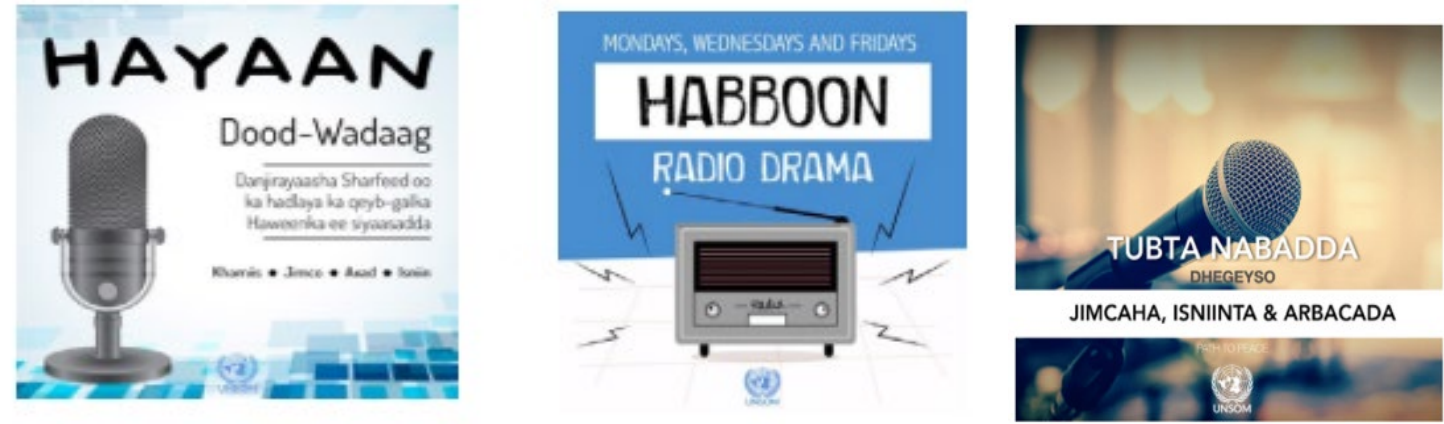

Source: A review on UNSOM's strategic communications in support of Somalia's 2016 Electoral process at https://unsom.unmissions.org/sites/default/files/20170915-electoal-process.pdf

- Social Media Campaigns
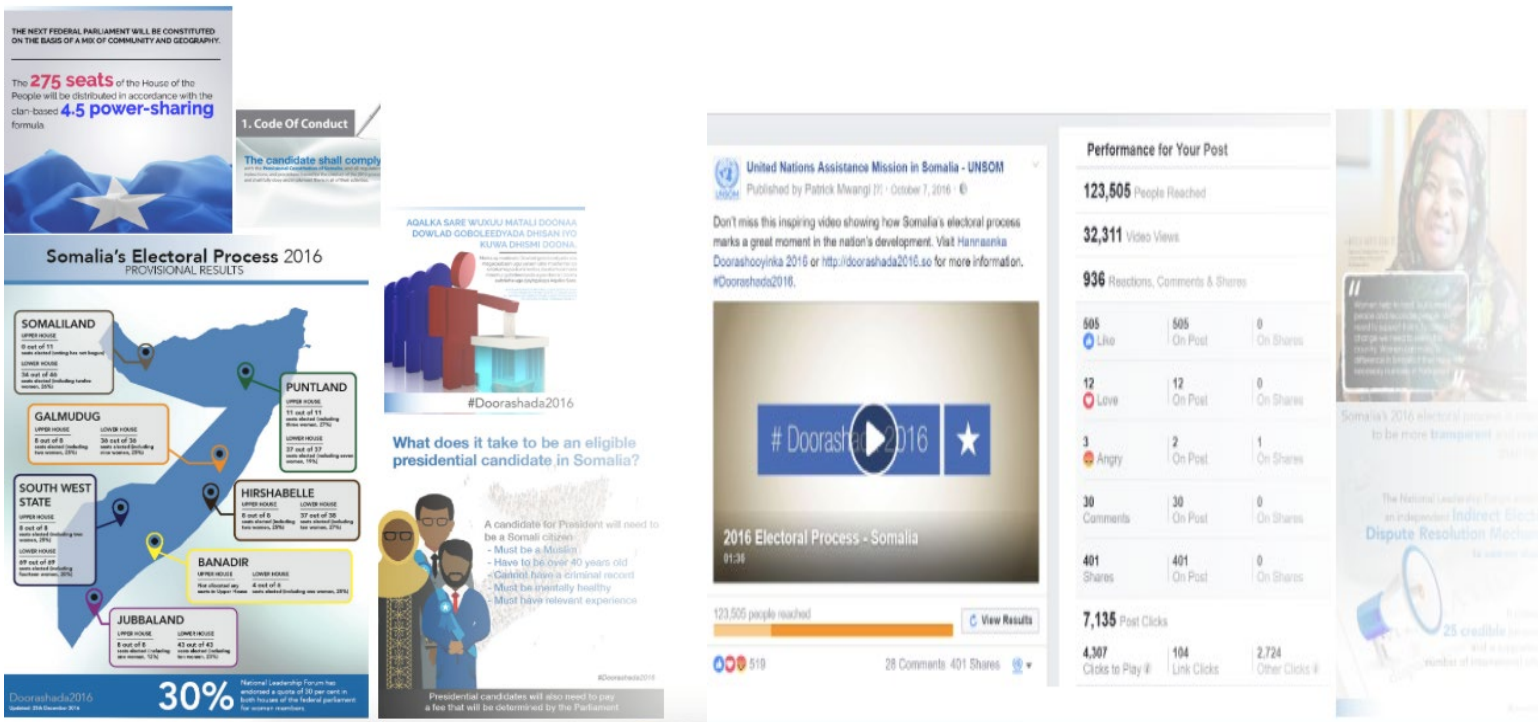

Source: A review on UNSOM's strategic communications in support of Somalia's 2016 Electoral process at https://unsom.unmissions.org/sites/default/files/20170915-electoal-process.pdf

- Radio Public Service Announcements

- Television products and animated videos about election and voting

Livestream coverage of the presidential voting as "Congratulations Somalia on the occasion of the Inauguration of a New President. We wish you a peaceful and prosperous future" (UNSOM, 2016).

\section{METHOD}

The aim of this research is to examine how the Vimeo videos cover issues related to Somalia's 2016 electoral process with regards to positive effects of UNSOM SCPAG. The main subjects of interest are the Somalia's 2016 Election and international actors in 
general and more precisely UNSOM SCPAG. This study sought answers to questions related to the approaches and positions the current peacekeeping operations, and their roles on serving facilities to develop professional media establishment in conflict areas. This study was interested in the application of solutions journalism in Somalia's 2016 Electoral process by UNSOM SCPAG facilitates.

The object of this study is video content-analysis both in terms of direct and implied meanings (Alexander et al., 2008). This study undertakes this through an endeavor to appreciate and evaluate the practices implemented by UNSOM SCPAG in their efforts on establishment not only professional media system in Somalia but also first application of solutions journalism. These analysis are based just on the actual 72 video material shared by Vimeo Somalia's 2016 Election Channel and UNSOM SCPAG whole activities in terms of solutions journalism application. The results will be based on the second generation and current peacekeeping operations characteristics of being multilateral, multidimensional, multicultural (Ramsbotham et al., 2005).

\section{RESULTS}

The conception of current peacekeeping played a role in informing environment from the conflict areas. In this study, UNSOM as whole mission were investigated about their SCPAG activities in support of Somalia's 2016 electoral process and about the role of establishment and application of solution journalism in Somalia's 2016 electoral process. The majority of the election process videos were in favor of the promotion of the 30 per cent quota of parliamentary seats for women candidates supporting the international media outreach activities. Contrary to some speculations about current peacekeeping operations in general and UNSOM more precisely UNSOM SCPAG, the results from the videos suggested that SCPAG played a key role in the design and production of a multifaceted package. UNSOM SCPAG multifaceted package includes public service announcements, radio talk shows and etc. and considered their primary goal to highlight the significance and greater inclusivity of this electoral process. With respect to the above mentioned information, answers to the following research question were sought:

- Did UNSOM SCPAG activities in Somalia, [a form of], 'solution journalism'during the period in Somalia's 2016 electoral process?

An overwhelming majority of videos (70 out of 72) conform to the notion of solution journalism because UNSOM SCPAG played the role of informing the voters about the possibilities of parliamentary seats for women candidates. For promotion to greater gender equity, Hayaan radio talk shows addressed women's participation in politics by producing radio drama series as young Somalia woman named by Habboon. With the help of the public service announcements prepared by the UNSOM SCPAG are promoted the empowerment of women in Somalia's 2016 electoral process, which $24 \%$ of members of new parliament became female.

Similarly, an overwhelming majority of videos (68 out of 72) fit the informative and educative notions of solution journalism. To this extend, UNSOM SCPAG civic education activities to promote the credibility of the electoral process have developed for not only endorse integrity but also legitimacy of electoral process. Significantly, weekly 30-minute radio program with animated videos were focused vital aspects such as; security, transparency and accountability. Therefore, it is important to say that UNSOM SCPAG with its informative and educative materials not only change the United Nations peacekeeping operations reputation of being over militaristic, it also shows that any United Nations peacekeeping operations might be helpful for not only political 
reconstruction in conflicted areas, but also influential in establishment of well-grounded media system of certain society. Thus, this animated videos it is clear to say that UNSOM SCPAG also provides an example of creativity in media sharing, which would be influential in enlarging the awareness. 'Nowadays, we are confronted with the fact that with non-professional creativity-based content media production and sharing. Therefore, these shares create new business opportunities for who are interested with creativity practices on social networks (Ciftci \& Evren, 2018: 386)

From the 72 of videos, it is crucial to express that UNSOM SCPAG has organized a series of two-day workshops for Somali journalists in six cities, which 125 journalists attended these workshops and have developed their capacitates for covering the electoral process and the UNSOM role in the electoral process. Relatively, international media outreach activities were vital to highlight the significance of the election. Therefore, as a solution journalism practice UNSOM SCPAG made an effort to mobilize interest in the 2016 electoral process among the international media outlets. With these videos UNSOM SCPAG ensured that the international community spoke with one voice on issues related to the process. Therefore, joint press statements regarding the political process on behalf of the international actors such as; UN, African Union, European Union, the InterGovernmental Authority on Development (IGAD), Ethiopia, Italy, Sweden, the United Kingdom and the United States were supported by UNSOM SCPAG.

On the other hand, UNSOM and international community's main goal was to enhance the governance in Somalia. Therefore, in 2016 all resources of the UNSOM and international communities' were used to support electoral process by concentrating on two important aspects of democratic election process: visibility and transparency of Goodwill Ambassadors, the Independent Electoral Dispute Resolution Mechanism (IEDRM) and the Federal Parliament. Apart from the videos presented by Vimeo UNSOM SCPAG was also support to the Federal Indirect Electoral Implementation Team (FIEIT) by providing extensive logistical and technical support. These supports included the FIEIT branding and later political marketing. UNSOM SCPAG was also beneficial for the FIEIT on not only creating an official social media accounts but also drafting of the media code of conduct. In this sense, FIEIT's official website, Facebook page and Twitter account designed by UNSOM SCPAG. Therefore, it is true to say that UNSOM SCPAG was also provide an example and reference point by creating these social media accounts which will be critical for future solutions journalism practices as well.

In addition, UNSOM SCPAG made an extensive efforts on supporting the Somali ownership of the political process by increasing the capacity of local media houses through journalism training workshops. Besides, communication strategies included the delivery of communications tools and social media platforms in order to grow promotional resources. At this point, UNSOM SCPAG also worked on the managing FIEIT public information office. Furthermore, UNSOM SCPAG another important activity was the arrangement of the translation of FIEIT's press statements and other official documents into English.

The intensified social media campaign generated by UNSOM SCPAG was another successful example of solution journalism on behalf of the Somalia's 2016 electoral process. Between July and November 2016, UNSOM Twitter account more than doubled with an average of 50 to 119 per month, which is approximately $33 \%$ increase compare with the period between March and June 2016. However, Tubta Nabadda (Path to Peace) was most important activity, which may be accepted as an actual solution journalism example. In Tubta Nabadda weekly 30-minute magazine talk shows during 14 weeks, 
Somalian women were mobilized to participate in the Somalia's 2016 electoral process. At the same time, Tubta Nabadda incorporates the different artists such as; musicians and comedians to reach broader and larger audience.

\section{DISCUSSION AND CONCLUSION}

Generally, the shortcomings of both first and second generation peacekeeping operations lead to approaching third generation peacekeeping. The context of collective human security identified as positive peace. Despite this kind of peace should operate with respect to satisfy human needs and protect human rights to promote economic equality and political participation. The multipronged mission of UN peacekeeping operations would be the reason of decline in second generation peacekeeping during the late 1990s. Of course positive peace should be applies in every possible area that were faced terrible conflicts, any defect in UN structure could negatively affected existing ceasefires or peaceful environment, it could also be the promoter for new conflicts. The new question had been arose 'is it need or greed' to pushes democracy, economic relief or anything related with Westernization.

Basically, taking into account all the lessons from Somalia, Rwanda and Bosnia in the third generation peacekeeping term UN needs some changes in its application by making peacekeeping mission based on more military robust rather than just monitoring as in the first generation peacekeeping. In addition, as a result of the facing terrible humanitarian disasters in the previous period, establishing international norm excessively by law order and human rights were highlighted. Yet, most of the think tanks published many reports which shape the UN third generation peacekeeping operations. Importantly, third generation peacekeeping operations was much more militaristic peacekeeping operations to be stronger in fighting aggressors, protecting civilians and protecting peace builders. In other words, instead of defensive mission in the third generation peacekeeping UN undertakes offensive military operations and peacebuilding or state-building. However, to avoid the failures that had experienced in Rwanda, Bosnia and Somalia, before applying any deployment should have pre-planning process which made UN military operations more realistic, achievable and clear. Therefore, activities are much more assertive and interventionist in nature.

The new peacekeeping was considered as much more militarily and politically active with operations through war-fighting to political machine to the foundation of new democratic governments in Somalia, Mozambique and Cambodia. Critically, the new peacekeeping could not be accepted as differ from traditional peacekeeping just by focusing its activities alone. To maintain humanitarian emergencies through consent of all parties has been difficult. Although the reason of acting in both Somalia and Former Yugoslavia was accepted as self-defense the rising use of force leads to interest-based and risks in any peacekeeping operations. In order to be more expressive in that point, it should be said that in the Somalia operation in particular with second generation peacekeeping operations chose to use maximum force in responses to UN causalities. Then the implications of this action would be similar to that contrary to traditional peacekeeping operations, new peacekeeping operations are alarming in terms of the shifting from endeavoring more traditional authority to more aggressive physical authority. The another differences between traditional peacekeeping and new peacekeeping operations were the launched position of UN command of a single nation is in contrast to the collective control of traditional peacekeeping. 
Comparing all these three peacekeeping operations it can be argued that first generation peacekeeping provides monitoring for already established ceasefire by intimidating role. Besides UN peacekeeping operations had to use minimum force which implies UN peacekeeping operations had instrumental role in peace process by using its power for diplomatic purposes to prevent violation of ceasefire. However, second generation peacekeeping since UN had intervened in the middle of the war; it fulfills the peacebuilding or even concludes conflict sometimes with no winner side. Gradually, in the third generation peacekeeping operations are much more extensive that provides monitoring, good offices to diplomatic channels. However, as a result of the idea of aid, founding and economic developments provided by NGOs, IOs, the role of UN's peacekeeping operations were very instrumental. Again, UN could have actor role by providing capacity to maintain coherent decision between different agencies.

The most fundamental principle of traditional peacekeeping of consent has remained a corner stone of not only past experiences both success and failure, but also current military peacekeeping. Since the principle of consent was not designated, so that it does differ from today's peacekeeping operations that we were facing in civil wars consent is uneven and incompatible. Significantly, operating without consent, UN have been facing its own security problem in hot war-fighting environment which will become its overriding and preoccupation. With the help of the Cyprus case one might make this criticism that peacekeeping freezes conflict but does not make peace, no one could tend to talk about human rights such as; right to property, right to self-determination and so on. On the other hand, one can also argue that this kind of human rights issues are out of UN responsibilities, then one question had been arose that: is that really success with regards to comprehensive meaning of 'peace'? As a result of the complexity of today's conflicts tends to peace approach multidimensional which implies that the infrastructure of conflict could not be reduces just by declaring ceasefires or freezing conflict. To get involved in the conflict area does conflict place require a permanent UN army to be really successful? From the possible answers it can be said that UN permanent army with the help of the changing nature in new wars started to take place not for need, but for greed that gives satisfaction to its existences and power. In the end rather than realist approach that highlights the ethnic religious link and state sovereignty within the UN especially the idea of 'keep it as it is' could sometimes damage the conceptualization of peace, whereas the functionalist approach that emphasizes the eliminating war and then promoting peace could be too general that meets problems as in the case of second generation peacekeeping operations. Therefore reformist approach could be most realistic one that is tried to find unitary interests that is to say 'human security'.

Solutions journalism as being a critical reporting for conflicted issues, UNSOM SCPAG in Somalia was massive example that indicates that it is applicable even in the cases where the unsuccessful UN peacekeeping operations occurred before. Therefore, as the results show that engaging peace settlement had to be changed with three important characteristics, which are also the bases for solutions journalism: multilateral, multidimensional, multicultural. As being multilateral character UNSOM SCPAG activities in general and more specifically videos that published put different actors conduct in involvement. In other words, based on the functionalist approach UNSOM SCPAG videos are not only creating networks between states, but also agencies can help eliminating social problems and promoting peace. On the other hand, UNSOM SCPAG videos as being multidimensional guarantee and maintain a secure environment for Somalia's 2016 electoral process. All in all, solutions journalism suggests the idea that 
social problems would be solved first accepting the differences and willing to see peaceful future that includes all these differences. Therefore, it is vital to say that UNSOM SCPAG had played crucial role in not only establishment of solutions journalism in Somalia by producing various types of materials, it also became a solutions journalists by itself by reporting the possible solutions for all social problems after the black days in Somalia.

This series of discussions from Somalia's case offers an opportunity to learn from residents in an underprivileged area whose voices are rarely heard might be changed by solutions journalism practices. In this sense, by educating journalists in the Somalia, UNSOM SCPAG had played a great role on how Somalian journalists their own community's story is told. Those videos and all other materials gave advice for how the journalists could better cover their own social problems at the same time by providing possible solutions. Therefore, after Somalia's 2016 electoral process, Somalian journalists awareness were raised on particular media preferences and practices. Clearly, the results show that solutions journalism with regards to videos produced by UNSOM SCPAG strengthened storytelling networks, which is primary way to develop local, communitybased solutions journalism. Thus, these networks with regards to videos were critical to long-term impacts on civic engagement in Somalia's 2016 electoral process. In solutions journalism workshops are important, UNSOM SCPAG provided various workshops for journalists and citizens, that have given opportunities to learn how to connect with media. These trainings are apparent in the videos that community members invest the best ways to communicate candidates, that should create critical feedback loops for cultivation to peace over the long term not only Somalia but also other conflicted areas as well.

The contribution of this study concentrated on the positive role of strategic communications units of peacekeeping operations by showing how media can make a constructive contribution to conflict prevention and peace building, how they can detect violence at an early stage and monitor the process of peace agreements. On the other hand, this study puts the role of the strategic communications and solutions journalism at increasing social cohesion and contribution to reconciliation. This study is also shows that a large degree of social cohesion by including women and any minority group in the peace building process would be successful with the strategic communication understanding parallel with the solution journalism ethics which prevent of the future conflict. Strategic communications and campaigns of Somalia case provides free and independent media environment that SCPAG aids local media development follows the conflict cycle and discusses the potential positive role of the media at any stage of cycle.

\section{REFERENCES}

A review of UNSOM's communications in support of Somalia's 2016 Electoral Process Available at: https://unsom.unmissions.org/sites/default/files/20170915-electoalprocess.pdf

Alexander, V. D., Thomas, H., Cronin, A., Fielding, J., \& Moran-Ellis, J. (2008). Mixed Methods. In N. Gilbert (ed.), Researching Social Life. London: Sage.

Aragones, E. (1997). Negativity effect and the emergence of ideologies. Journal of Theoretical Politics, 9(2), 189-210. https://doi.org/10.1177/0951692897009002003

Bellamy, A., Williams, P., \& Griffin, S. (2004). Understanding Peacekeeping. London: Polity.

Brader, T. (2005). Striking a responsive chord: How political ads motivate and persuade voters by appealing to emotions. American Journal of Political Science, 49(2), 388405. https://doi.org/10.1111/j.0092-5853.2005.00130.x 
Online Journal of Communication and Media Technologies, 2019

Çatal, Ö. (2017). New Technologies Challenging the Practice of Journalism and The Impact of Education: Case of Northern Cyprus. Eurasia Journal of Mathematics, Science and Technology Education, 13(11), 7463-7472. https://doi.org/10.12973/ejmste/79975

Ciftci, D. (2014). Peace journalism and news coverage on the annan plan referendum: the role of framing the conflict issues and negotiation process. GSTF Journal on Media and Communications (JMC), 1(2). https://doi.org/10.5176/2335-6618_1.2.19

Ciftci, D., \& Evren, F. B. (2018). A New Creative Culture Example: The Case of the 'What will be Happen News Bulletin'in North Cyprus. Online Journal of Communication and Media Technologies, 8(4), 385-398. https://doi.org/10.12973/ojcmt/3959

Cohen, S. (2013). States of denial: Knowing about atrocities and suffering. John Wiley \& Sons.

Cooper, R. (2001). Un-timely mediations: Questing thought. Ephemera: Critical Dialogues On Organization, 1(4), 321-47.

Feinberg, M., \& Willer, R. (2011). Apocalypse soon? Dire messages reduce belief in global warming by contradicting just-world beliefs. Psychological science, 22(1), 34-38. https://doi.org/10.1177/0956797610391911

Galtung, J., \& Ruge, M. H. (1965). The structure of foreign news: The presentation of the Congo, Cuba and Cyprus crises in four Norwegian newspapers. Journal of peace research, 2(1), 64-90. https://doi.org/10.1177/002234336500200104

Kurpius, D. D. (2002). Sources and civic journalism: Changing patterns of reporting? Journalism \& Mass Communication Quarterly, 79(4), 853-866. https://doi.org/10.1177/107769900207900406

Laqua, D. (2015). Democratic Politics and the League of Nations: The Labour and Socialist International as a Protagonist of Interwar Internationalism. Contemporary European History, 24(2), 175-192. https://doi.org/10.1017/S0960777315000041

Meffert, M. F., Chung, S., Joiner, A. J., Waks, L., \& Garst, J. (2006). The effects of negativity and motivated information processing during a political campaign. Journal of Communication, 56(1), 27-51. https://doi.org/10.1111/j.14602466.2006.00003.x

Pedersen, S. (2015). The Guardians: The League of Nations and the Crisis of Empire. Oxford: Oxford Press. https://doi.org/10.1093/acprof:oso/9780199570485.001.0001

Ramsbotham, O., Woodhouse, T., \& Miall, H. (1999). Contemporary Conflict Resolution: The Prevention, Management and Transformation of Deadly Conflicts. London: Polity.

Ramsbotham, O., Woodhouse, T., \& Miall, H. (2005). Contemporary Conflict Resolution: The Prevention, Management and Transformation of Deadly Conflicts. London: Polity.

Rosen, J. (1999). The challenge of public journalism. The Idea of Public Journalism, 44.

Ryan, S. (2000). United Nations Peacekeeping: A Matter of Principles? International Peacekeeping, 7(1), 27-4. https://doi.org/10.1080/13533310008413817

Shah, D. V., McLeod, D. M., Kim, E., Lee, S. Y., Gotlieb, M. R., Ho, S. S., \& Breivik, H. (2007). Political consumerism: How communication and consumption orientations drive "lifestyle politics". The ANNALS of the American Academy of Political and Social Science, 611(1), 217-235. https://doi.org/10.1177/0002716206298714 
Sheldon, Z., \& Romanowski, M. (2018). Amazing! Two Graduate Students Wrote About Stupid Internet Stuff and Got Away with It! (Page 10 Will Blow Your Mind!). Online Journal of Communication and Media Technologies, 8(4), 293-307. https://doi.org/10.12973/ojemt/3953

Solutions Journalism Network available at https://www.solutionsjournalism.org

Ulas, S., \& Vural, Z. B. (2019). Social Media Usage Practices of Luxury Brands: A Case of Luxury Automobile Brands' Corporate Social Media Applications. Online Journal of Communication and Media Technologies, 9(1), 1-16. https://doi.org/10.29333/ojcmt/5723

Wenzel, A., Gerson, D., \& Moreno, E. (2016). Engaging communities through solutions journalism. New York: Columbia Journalism School.

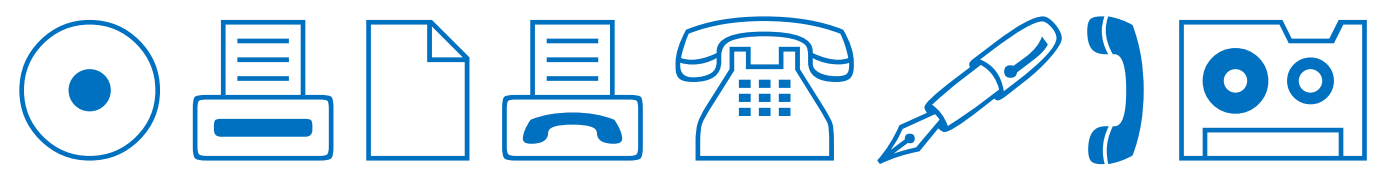

